\title{
Characterization of Induced Sugarcane Somaclones and their Sources Varieties Using Random Amplified Polymorphic DNA
}

\author{
Kuasha Mahmud ${ }^{*}$, K. M. Nasiruddin ${ }^{1}$, M. A. Hossain and \\ L. Hassan ${ }^{2}$ \\ Biotechnology Division, Bangladesh Sugarcane Research Institute, Ishurdi, Pabna \\ Key words: Sugarcane, Somaclones, Variation, RAPD and UPGMA
}

\begin{abstract}
Sugarcane somaclones and their sources varieties were analyzed by RAPD molecular markers to check the variation at molecular level based on $1.4 \%$ agarose gel electrophoresis (AGE). Six RAPD primers generated 237 bands with average 39.5 varied from 15 to 63 with size ranging 145 - $1000 \mathrm{bp}$ among the four sugarcane varieties and their 12 somaclones. Genetic diversity or polymorphism information content (PIC) value ranged from 0.39 to 0.50 for all loci across the 4 varieties and their 12 somaclones based on RAPD markers. Dendrogram based on linkage distance using unweighted pair group method of arithmetic means (UPGMA) based on 6 RAPD primers indicated segregation of the 4 sugarcane varieties and their somaclones into two main clusters at linkage distance 36. Variety Isd 39 was observed in main cluster $C_{1}$ while its (Isd 39) somaclones and other varieties (Isd 37, Isd 38 and Isd 40) and also their somaclones were found in main cluster $\mathrm{C}_{2}$ having different sub-clusters. Theirfore, it may be concluded that RAPD markers can be used for identification of somaclonal variation and the relationship between sources varieties and their somaclones.
\end{abstract}

\section{Introduction}

Sugarcane is globally a major source of raw material for the production of commercial sugar and has multipurpose crop providing not only sugar, but also a series of value added products and by-products such as energy, chemicals, and

*Author for correspondence: <kmahmud31@yahoo.com>. ${ }^{1}$ Department of Biotechnology, Bangladesh Agricultural University, Mymensingh. ${ }^{2}$ Department of Genetics \& Plant Breeding, Bangladesh Agricultural University, Mymensingh. 
single cell protein, ethanol, bio-gas, fertilizer, fibre board and paper, polishers, cosmetics and candles. Although many countries are producers, only six of them account for $65 \%$ of the world's entire sugarcane production. Among these Brazil is the largest one (Viera 2002). It is very urgent to increase cane productivity without further area expansion to meet the future need of sugar and gur. The chemical composition of a matured, sound and normal sugarcane stalk of the species Saccharum officinarum are water $74.96 \%$, sugar $13.40 \%$, fibre $10.04 \%$, ash $0.64 \%, \mathrm{~N}_{2}$ bodies $0.58 \%$, fat and wax $0.38 \%$. Sugarcane is propagated vegetatively for commercial planting by stem cuttings. Tissue culture offers an opportunity to mass produce disease free planting material and is now used to supplement commercial sugarcane propagation in many countries including Brazil, the United States, India and Cuba (Lakshmanan et al. 2006). Somaclones may show variation for different parameters like yield, sugar recovery, disease resistance, drought and salt tolerance, maturity etc. It is not controversial that tissue culture tools are playing their part in sugarcane improvement and at the same time for a plant breeder assessment of genetic diversity.

Genetic markers have contributed much to understanding plant genetic diversity. Molecular markers are extensively being used to measure the variability present at genetic level, within and among the genotypes. The most commonly applied molecular markers used to study polymorphism are random amplified polymorphic DNA (RAPD).

The objectives have been planned for four explant sources varieties viz., Isd 37, Isd 38, Isd 39 and Isd 40 in order to develop somaclones as well as to calculate the genetic variability in the somaclones compared to their sources varieties by the use of DNA markers such as RAPD. These informations certainly will facilitate the supplementation of the breeding programme prevailing in Bangladesh.

\section{Materials and Method}

The experiment was conducted at the Biotechnology Laboratory, Bangladesh Sugarcane Research Institute (BSRI), Ishurdi, Pabna, Bangladesh during 2010 to 2011 to obtain in vitro plant regeneration potentiality of BSRI released varieties Isd 37, Isd 38, Isd 39 and Isd 40. The leaf sheath explants were collected from 8 10 months old field grown sugarcane from BSRI experimental field. At first MS supplemented with green coconut water $(10 \%)$ containing $3 \mathrm{mg} / \mathrm{l}$ of 2, 4-D was prepared for callus induction. After five weeks of explantation, the calli were inoculated for shooting on MS supplemented with concentration BAP (2 mg/l) + $\mathrm{Kn}(1 \mathrm{mg} / \mathrm{l})$ and maintained by sub-culturing every two weeks and then regenerated shoots were inoculated for rooting by sub-culturing every two 
weeks on MS supplemented with $5 \mathrm{mg} / \mathrm{l}$ NAA. Rooted plantlets were acclimatized and transplanted to polybag and then field, respectively.

For molecular studies, young meristem cylinder from 12 somaclones and their donor parents were taken from $\mathrm{R}_{0}$ regeneration and grinded using extraction buffer solution and amount of chemicals were important considerations for DNA isolation. DNA was extracted from sugarcane using the method modified and combined from the methods of Aljanabi et al. (1999) and mini-prep method adopted from Hossain et al. (2006) and Shahnawaz (2006). The DNA concentration was determined by Nano drop Spectrophotometer (2000/2000c, Thermo Scientific, USA) and was diluted to a concentration of $50 \mathrm{ng} / \mu \mathrm{l}$. Samples were stored at $-20^{\circ} \mathrm{C}$ for further use. Polymorphism was studied using RAPD as illustrated by Mondal et al. (2009) which supported by Williams et al. (1990). Six RAPD primers (Operon Technologies, Inc., Alameda, California, USA) were used. List of polymorphic primers and their sequences are subsequently given.

The reaction mixtures $10 \mu \mathrm{l}$ was amplified for each DNA sample in a Thermal Cycler (Genius, Techne, Cambridge Ltd.). Agarose gel (1.4\%, w/v) was used for RAPD electrophoresis. The ethidium bromide at $10 \mathrm{mg} / \mathrm{ml}$ was added in gel for detection. Bands were viewed under ultraviolet trans-illuminator and documentation (FluorChem FC2, Cell Biosciences, USA) and also analysis system was used to make photographs. Besides, it was printed and saved on CD for lateral use.

The presence and absence of a DNA fragment was considered as basis of polymorphism. DNA loci if present were scored as ' 1 ' and if not were scored as ' 0 '. The number of alleles per locus was determined and the polymorphic information content (PIC) values were calculated using the formula (Mondal et al. 2009). A dendrogram was constructed by using uweighted pair group method of arithmetic means (UPGMA) algorithm (Sneath and Sokal 1973) provided in the software (Statistica computer package).

\section{Results and Discussion}

In this study, six RAPD markers were used to measure the variability present in the 12 somaclones along with their parents generated through somaclonal variation. Although, nowadays, the different types of molecular markers are increasingly being used to study the distribution and patterns of genetic diversity in populations.

A total number of 175 DNA fragments were polymorphic indicating $74.67 \%$ polymorphism while 128 were unique bands. The average number of DNA polymorphic fragments produced by each primer was 29.17. The size of 
amplification products ranged from 145 to $1000 \mathrm{bp}$ (Table 1). The maximum number of polymorphic bands (45) was produced by the primer OPA-04, while the minimum number (12) was produced by primer OPA-01. Primer OPA-07 depicted maximum (80.56\%) polymorphism followed by primers OPA-01 $(80.00 \%)$ and OPB-06 (74.13\%). Primer OPB-05 was found to be least polymorphic with $68.57 \%$ polymorphism.

Table 1. Performance of bands and PIC values as influenced by various RAPD primers among sixteen sugarcane genotype.

\begin{tabular}{ccccccc}
\hline $\begin{array}{c}\text { Primer } \\
\text { codes }\end{array}$ & $\begin{array}{c}\text { Size ranges } \\
\text { (bp) }\end{array}$ & $\begin{array}{c}\text { No. of } \\
\text { polymorphic } \\
\text { bands }\end{array}$ & $\begin{array}{c}\text { No. of unique } \\
\text { bands }\end{array}$ & $\begin{array}{c}\text { Polymor- } \\
\text { phism (\%) }\end{array}$ & $\begin{array}{c}\text { Number of } \\
\text { bands/genotype }\end{array}$ & $\begin{array}{c}\text { PIC } \\
\text { value }\end{array}$ \\
\hline OPA - 01 & $357-711$ & 12 & 10 & 80.00 & 0.93 & 0.39 \\
OPA - 02 & $278-988$ & 22 & 17 & 73.33 & 1.88 & 0.46 \\
OPA - 04 & $165-1000$ & 45 & 29 & 71.43 & 3.94 & 0.50 \\
OPB - 05 & $365-955$ & 24 & 16 & 68.57 & 2.19 & 0.49 \\
OPB - 06 & $145-944$ & 43 & 30 & 74.13 & 3.63 & 0.49 \\
OPA - 07 & $258-1000$ & 29 & 26 & 80.56 & 2.25 & 0.50 \\
\hline Total & - & 175 & 128 & 448.02 & 14.82 & 2.83 \\
Average & - & 29.17 & 21.33 & 74.67 & 2.47 & 0.47 \\
\hline
\end{tabular}

The PIC indicates the effective number of alleles that can be detected per marker in a set of individuals. It is the the discriminatory power of the marker. Data depict that the PIC value ranges from 0.39 to 0.50 . Maximum PIC value 0.50 was detected by primers OPA-04 and OPA-07 followed by primer OPB-05 and OPB-06 with 0.49 PIC value.

Detection of somaclonal variation through RAPD markers have been applied in sugarcane by many workers (Saini et al. 2004, Jain et al. 2005, Suprasanna et al. 2006, 2007, Devarunmath et al. 2007). Lal et al. (2008) investigated variability in sugarcane genotypes using 16 RAPD primers and amplified a total of 110 scorable fragments. Nair et al. (2002) used 25 RAPD primers to detect variability in 28 elite Indian sugarcane varieties and they observed $63.74 \%$ polymorphism.

Genetic diversity is commonly measured by genetic distance of genetic similarity, which signifies that there are either differences or similarities present at the genetic level (Weir 1990). The greatest linkage distance (44) was recorded between somaclone CC-40-6 and variety Isd 39 followed by linkage distance (43) between somaclones CC-40-2 and CC-40-6. Variety Isd 37 had the least linkage distance (14) with somaclone CC-40-3. Besides, Isd 37 had linkage distance 19, 28 and 24 with other varieties Isd 38, Isd 39 and Isd 40, respectively. Somaclones CC-37-1, CC-37-4 and CC-37-5 had linkage distance 22, 25 and 26 with their 
parent variety Isd 37. Somaclones CC-38-1, CC-38-2 and CC-38-5 had linkage distance 23, 21 and 25 with their parent variety Isd 38. Parent variety Isd 39 exhibited linkage distance 31, 36 and 33 with CC-39-3, CC-39-5 and CC-39-6, respectively. Furthermore, parent variety Isd 40 showed linkage distances 35, 24 and 36 with its somaclones CC-40-2, CC-40-3 and CC-40-6, respectively. The least linkage distance between parent and somaclone indicates that maximum changes occurred at the chromosomal or gene level (Table 2).

Table 2. Summary of linkage distances (based on statistica) values for different genotype pairs of sugarcane.

\begin{tabular}{|c|c|c|c|c|c|c|c|c|c|c|c|c|c|c|c|c|}
\hline $\begin{array}{c}\text { Varieties/ } \\
\text { somaclones }\end{array}$ & $\begin{array}{l}\hat{\infty} \\
\text { 苟 } \\
0\end{array}$ & $\begin{array}{l}\text { T } \\
\text { ôn } \\
u \\
u\end{array}$ & $\begin{array}{l}+1 \\
\text { Ô } \\
\text { ú }\end{array}$ & $\begin{array}{l}p \\
\hat{n} \\
\tilde{u} \\
ن\end{array}$ & $\begin{array}{l}\infty \\
\infty \\
0 \\
0 \\
n\end{array}$ & $\begin{array}{l}\vec{J} \\
\infty \\
0 \\
u \\
u\end{array}$ & $\begin{array}{l}N \\
\infty \\
0 \\
U \\
U\end{array}$ & $\begin{array}{l}p \\
\infty \\
\infty \\
u \\
u\end{array}$ & $\begin{array}{l}\text { के } \\
\text { ర్ల }\end{array}$ & $\begin{array}{l}p \\
1 \\
0 \\
u \\
u\end{array}$ & $\begin{array}{l}p \\
0 \\
\text { ô } \\
u \\
u\end{array}$ & $\begin{array}{l}0 \\
1 \\
0 \\
0 \\
u \\
u\end{array}$ & 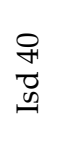 & 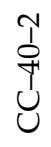 & $\begin{array}{l}p \\
\substack{1 \\
ن} \\
ن\end{array}$ & $\begin{array}{l}0 \\
0 \\
0 \\
y \\
ن\end{array}$ \\
\hline Isd 37 & 0 & 22 & 25 & 26 & 19 & 24 & 16 & 22 & 28 & 17 & 22 & 19 & 24 & 27 & 14 & 30 \\
\hline CC-37-1 & 22 & 0 & 31 & 30 & 23 & 30 & 20 & 28 & 38 & 25 & 24 & 21 & 32 & 33 & 20 & 36 \\
\hline CC-37-4 & 25 & 31 & 0 & 35 & 28 & 27 & 23 & 29 & 35 & 28 & 31 & 28 & 35 & 38 & 23 & 37 \\
\hline CC-37-5 & 26 & 30 & 35 & 0 & 29 & 34 & 26 & 32 & 42 & 29 & 32 & 29 & 36 & 37 & 24 & 36 \\
\hline Isd 38 & 19 & 23 & 28 & 29 & 0 & 23 & 21 & 25 & 35 & 22 & 25 & 22 & 29 & 30 & 17 & 33 \\
\hline CC-38-1 & 24 & 30 & 27 & 34 & 23 & 0 & 26 & 28 & 34 & 27 & 30 & 27 & 34 & 37 & 22 & 38 \\
\hline CC-38-2 & 16 & 20 & 23 & 26 & 21 & 26 & 0 & 24 & 34 & 19 & 24 & 21 & 26 & 31 & 16 & 32 \\
\hline CC $-38-5$ & 22 & 28 & 29 & 32 & 25 & 28 & 24 & 0 & 30 & 25 & 30 & 27 & 34 & 35 & 22 & 36 \\
\hline Isd 39 & 28 & 38 & 35 & 42 & 35 & 34 & 34 & 30 & 0 & 31 & 36 & 33 & 42 & 43 & 28 & 44 \\
\hline CC-39-3 & 17 & 25 & 28 & 29 & 22 & 27 & 19 & 25 & 31 & 0 & 23 & 22 & 27 & 28 & 17 & 29 \\
\hline$C C-39-5$ & 22 & 24 & 31 & 32 & 25 & 30 & 24 & 30 & 36 & 23 & 0 & 23 & 32 & 35 & 20 & 32 \\
\hline CC-39-6 & 19 & 21 & 28 & 29 & 22 & 27 & 21 & 27 & 33 & 22 & 23 & 0 & 29 & 32 & 15 & 33 \\
\hline Isd 40 & 24 & 32 & 35 & 36 & 29 & 34 & 26 & 34 & 42 & 27 & 32 & 29 & 0 & 35 & 24 & 36 \\
\hline CC $-40-2$ & 27 & 33 & 38 & 37 & 30 & 37 & 31 & 35 & 43 & 28 & 35 & 32 & 35 & 0 & 27 & 43 \\
\hline CC $-40-3$ & 14 & 20 & 23 & 24 & 17 & 22 & 16 & 22 & 28 & 17 & 20 & 15 & 24 & 27 & 0 & 26 \\
\hline CC-40-6 & 30 & 36 & 37 & 36 & 33 & 38 & 32 & 36 & 44 & 29 & 32 & 33 & 36 & 43 & 26 & 0 \\
\hline
\end{tabular}

Genetic relationship among the 12 somaclones and their 4 parents (Isd 37, Isd 38 , Isd 39 and Isd 40) generated some different cluster at the linkage distance range from 36 to 14 by all of the 6 primers. Dendrogram based on linkage distance using indicated segregation of the 4 sugarcane varieties and their somaclones into two main clusters $C_{1}$ (Isd 39) and $C_{2}$ at the linkage distance of 36 (Fig. 1). Besides, $\mathrm{C}_{2}$ produced different sub clusters. Formation of clustering and sub clustering in the tree diagram confirmed the presence of variability at DNA level among somaclones with respect to their parents. Nevertheless, it is also suggested that to get more precise results, the number of primers should be increased. Very limited reports on the use of DNA markers for the estimation of 
somaclonal variation are available. Hence, this study can be used as a point reference for further studies.

Tree Diagram for 4 Sugarcane Varieties and Their Somaclones Based on RAPD Marker Unweighted pair-group average

Squared Euclidean distances

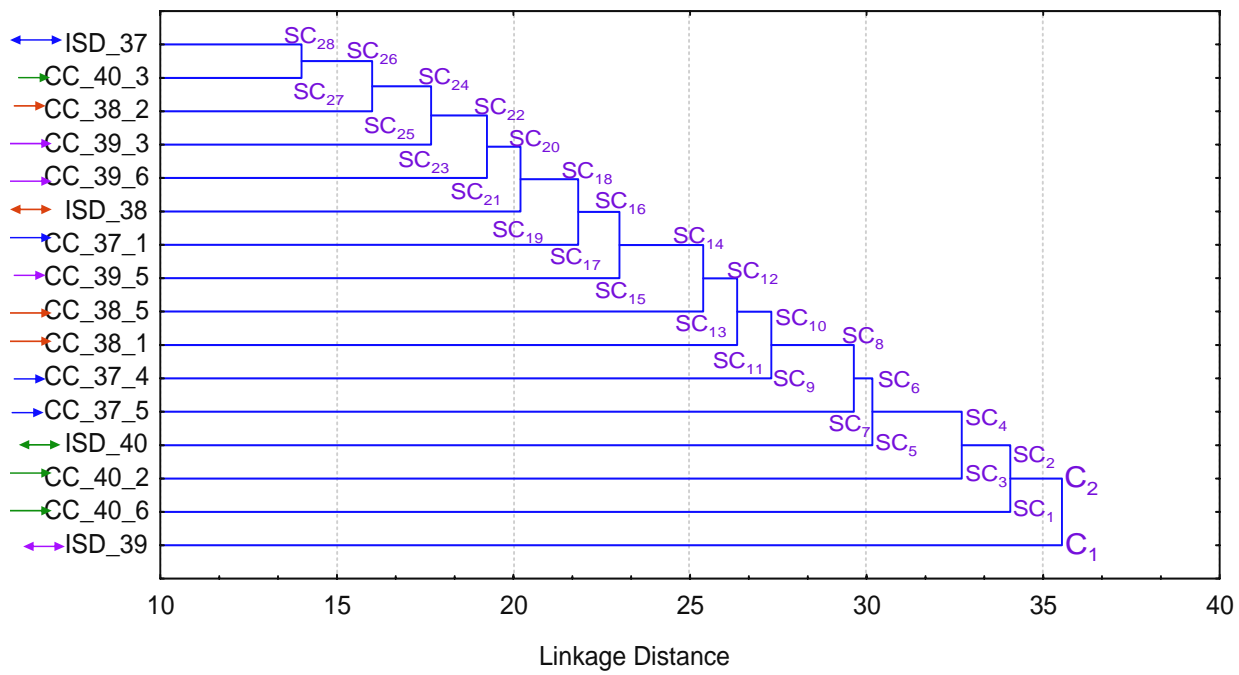

Fig. 1. Cluster analysis by UPGMA means of four sugarcane varieties and their somaclones based on 6 RAPD markers. $(\mathrm{C}=$ Cluster, $\mathrm{SC}=$ Sub-cluster $)$.

\section{References}

Aljanabi SM, Forget L and Dookun A (1999). An improved rapid protocol for the isolation of polysaccharide and polyphenol-free sugarcane DNA. Plant Mol. Biol. Rep. 17: 1-8.

Devarumath RM, Doule RB, Kawar PG, Naikebawane SB and Nerker YS (2007). Field performance and RAPD analysis to evaluate genetic fidelity of tissue culture raised plants vis-à-vis conventional setts derived plants of sugarcane. Sugar Tech 9(1): 17-22.

Jain R, Srivastava S, Singh J and Gupta PS (2005). Assessment of genetic purity of micropropagated plants of sugarcane by isozyme and RAPD analysis. Sugar Tech 7(2\&3): 15-19.

Lakshmanan P, Geijskes RJ, Wang L, Elliott A, Grof CPL, Berding N and Smith GR (2006). Development and hormonal regulation of direct shoot organogenesis and somatic embryogenesis in sugarcane (Saccharum spp. Interspecific hybrids) leaf culture. Plant Cell Rep. 25: 1007-1015.

Lal M, Singh RK, Srivastava S, Singh N, Singh SP and Sharma ML (2008). RAPD marker based analysis of micropropagated plantlets of sugarcane for early evaluation of genetic fidelity. Sugar Tech 10(1): 99-103. 
Hossain MA, Shaik MM, Shahnawaz RMS, Islam N and Miah MAS (2006). Quality DNA isolation using different methods of sugarcane (Saccharum officinarum L.). Bangladesh J. Sugarcane 28: 65-69.

Mondal S, Sutar SR and Badigannavar AM (2009). Assesssment of genetic diversity in cultivated groundnut (Arachis hypogaea L) with differential responses to rust and late spot using ISSR markers. J. Genet. Plant Breed 63(3): 219-224.

Nair NV, Selvi A, Sreenivasan TV and Pushpalatha KN (2002). Moleculer diversity in Indian sugarcane cultivars as revealed by Randomly Amplified DNA Polymorphsms. Euphitica 127: 219-225.

Shahnawaz RMS (2006). DNA isolation, quantification and fingerprinting using RAPD markers of sugarcane (Saccharum officinarum L.). A thesis of Master's of Science (M.Sc) in Biotechnology and Genetic Engineering Dept., Islamic University, Kushtia, Bangladesh.

Sneah PHA and Sokal RR (1973). Numerical taxonomy. W.H., Freeman and Co., San Francisco, CA pp. 21-28.

Suprasanna P and Bapat VA (2006). Advances in the development of in vitro culture systems and transgenics in sugarcane. Int. Symp. Technologies to improve productivity in developing countries. China pp 629-636.

Saini N, Saini ML and Jain PK (2004). Large scale production, field performance and RAPD analysis of micropropagated sugarcane plants. Ind. J. Genet 64: 102-107.

Viera (2002). Genetic stability of sugarcane plants derived from meristem culture. Genetic and Molecular Biology 235(1): 91-96.

Williams JGK, Kubelik AR, Livak KJ, Rafalski J.A and Tingey SV (1990). DNA polymorphisms amplified by arbitrary primers are useful as genetic markers. Nucleic Acids Res. 18: 6531-6535. 